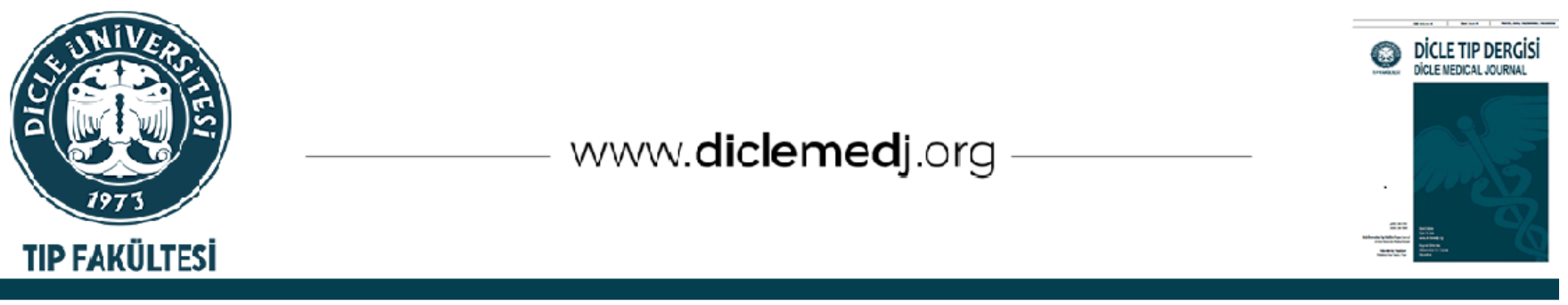

Original Article / Özgün Araştırma

\title{
Comparison of hematological inflammatory parameters in patients with exfoliative glaucoma and exfoliative syndrome
}

\author{
Atılım Armağan Demirtaş ${ }^{\left(D_{1}\right.}$, Mine Karahan ${ }^{\left(D_{2}\right.}$ \\ 1 Department of Ophthalmology, Health Sciences University, Izmir Tepecik Training and Research Hospital, Izmir, Turkey \\ 2 Department of Ophthalmology, Dicle University Faculty of Medicine, Diyarbakır, Turkey
}

Received: 12.01.2021; Revised: 23.02.2021; Accepted: 23.02.2021

\begin{abstract}
Objective: To evaluate the neutrophil / lymphocyte ratio (NLR), platelet / lymphocyte ratio (PLR), and systemic immune inflammation index (SII) in exfoliative glaucoma (XFG) patients with the aim of comparing the findings with those of healthy controls and exfoliative syndrome (XFS) patients.

Methods: In this retrospective cross-sectional study included 134 participants, 22 XFG patients, 41 XFS patients and 71 healthy individuals were examined. Peripheral venous sample values including neutrophil, lymphocyte and platelet levels were recorded from the hospital database.

Results: Among evaluated hematological parameters, although the NLR values of the subjects with XFG were greater than those of the subjects with XFS, when the relationship between the NLR, PLR and SII parameters of the XFG and XFS groups, adjusted for age and gender, was examined by logistic regression analysis, no significant difference was found between the groups. Multiple linear regressions of the association between the NLR, PLR and SII parameters and the ocular parameters of the XFG and XFS groups revealed no significant relationship between the blood parameters and ocular measurements. Neutrophil / lymphocyte ratio was found to be the most acceptable discriminant parameter when comparing XFG group with the XFS and control groups (AUC [area under curve] $=0.678, A U C=0.663$, respectively). Platelet / lymphocyte ratio was found to be the best discriminant parameter between the XFS and control groups (AUC=0.605).

Conclusion: No significant difference was found between XFG and XFS groups in terms of NLR, PLR and SII parameters. Considering the fact that NLR has the best AUC when comparing XFG and XFS groups, it may be the most acceptable discriminant parameter between XFG and XFS.
\end{abstract}

Keywords: exfoliative glaucoma, exfoliative syndrome, neutrophil, platelet, systemic immune inflammation index

DOI: 10.5798/dicletip.887421

Correspondence / Yazışma Adresi: Atılım Armağan Demirtaş, Dept. of Ophthalmology, Health Sciences University, Izmir Tepecik Training and Research Hospital, Izmir, Turkey e-mail: atilimdemirtas77@gmail.com 


\section{Eksfoliatif glokom ve eksfoliatif sendromlu hastalarda hematolojik enflamatuar parametrelerin karşılaştırılması}

Öz

Amaç: Eksfoliatif glokom (XFG), eksfoliatif sendrom (XFS) hastalarında ve sağlıklı kontrollerde nötrofil / lenfosit oranı (NLO), platelet / lenfosit oranı (PLO) ve sistemik immün enflamasyon indeksini (Sií) karşılaştırmak amaçlandı.

Metod: Retrospektif kesitsel çalışmamızda 22 XFG'lu, 41 XFS'lu ve 71 sağlıklı bireyden oluşan toplam 134 katılımcı incelendi. Nötrofil, lenfosit ve trombosit düzeylerini içeren periferik venöz örnek değerleri hastane veri tabanından kaydedildi.

Bulgular: Değerlendirilen hematolojik parametreler arasında, XFG'lu olguların NLO değerleri XFS'lu olgulardan daha yüksek olmasına rağmen, XFG ve XFS gruplarının NLO, PLO ve Si̇ parametrelerinin yaş ve cinsiyet açısından düzeltilmiş ilişkileri lojistik regresyon analiziyle incelendiğinde gruplar arasında anlamlı farklılık bulunmadı. XFG ve XFS gruplarının NLO, PLO ve Si̇ parametreleri ile oküler parametrelerinin yaş ve cinsiyet açısından düzeltilmiş ilişkileri çoklu doğrusal regresyon analiziyle incelendiğinde her iki grupta da kan parametreleri ile oküler ölçümleri arasında anlamlı ilişki bulunmadı. XFG grubu; XFS ve kontrol grupları ile karşılaștırıldı̆̆ında, NLO'nın en kabul edilebilir ayırt edici parametre olabileceği bulundu (sırasıyla AUC [area under curve] $=0.678$, AUC=0.663). Platelet lenfosit oranının, XFS ve kontrol grupları arasında en iyi ayırt edici parametre olabileceği bulundu (AUC=0.605).

Sonuç: Nötrofil / lenfosit oranı, PLO ve Si̇ parametreleri açısından XFG ve XFS grupları arasında anlamlı farklılık bulunmadı. Eksfoliatif glokom ve XFS karşılaştırıldığında en iyi AUC'a sahip olan NLO, XFG ve XFS arasında en kabul edilebilir ayırt edici bir parametre olabilir.

Anahtar kelimeler: eksfoliatif glokom, eksfoliatif sendrom, nötrofil, platelet, sistemik immün enflamasyon indeksi.

\section{INTRODUCTION}

Hematological indicators of systemic inflammatory conditions obtained from peripheral venous sampling, including the neutrophil / lymphocyte ratio (NLR), platelet / lymphocyte ratio (PLR), lymphocyte / monocyte ratio (LMR), serum lipid levels, and the systemic immune inflammation index (SII), have been proposed as prognostic indicators in several inflammatory disorders and malignancies ${ }^{1-9}$.

It has been the subject of many studies that there may be markers showing the association of some ocular diseases and systemic inflammation. These markers, including NLR, PLR, LMR, monocyte / high density lipoprotein ratio, and SII can be evaluated together with the ocular findings in evaluating the progression of ocular diseases $3,5,10-23$. It has been reported that among these parameters, NLR and PLR may be the best distinctive diagnostic parameters, especially in exfoliative syndrome (XFS) and glaucoma $(\mathrm{XFG})^{11,13}$.

Whether the aferomentioned indicators are associated with XFG still lacks evaluation and needs to be further examined. Main outcome of our study was to investigate the NLR, PLR, and SII in XFG patients with the aim of comparing the findings with those of healthy controls and XFS patients. Furthermore, we aimed to study the correlations between these biomarkers and the ocular parameters of XFG and XFS patients.

\section{METHODS}

This retrospective cross-sectional research included 134 individuals with 22 patients with bilateral XFG, 41 patients with bilateral XFS and 71 control subjects. Study participants were selected between January 2019 and May 2019. Moreover, the research protocol was approved by the Ethics Committee of Diyarbakır Gazi Yaşargil Training and Research Hospital (date/number: 14.06.2019/292) and the study was conducted in accordance with the Helsinki 
Declaration. All subjects included in this study provided their written informed consent. Patients with XFG were included in Group 1, patients with XFS in Group 2, and healthy participants presenting with presbyopia and no ocular pathology were included in Group 3. Detailed medical anamnesis was recorded, and the patients were interviewed about the drugs they routinely consumed. Patients with a history of systemic inflammatory diseases, inflammatory eye diseases, diabetes mellitus, anemia, myocardial infarction, connective tissue diseases were excluded from the study.

A full ophthalmologic assessment was performed on the subjects in the study groups. Best-corrected visual acuity was recorded with Snellen chart, and intraocular pressures were measured with Goldmann applanation tonometer. Biomicroscopic anterior segment and fundus examination was performed. Retinal nerve fiber layer thickness (RNFLT) values were recorded by optical coherence tomography (Spectralis; Heidelberg Engineering, Heidelberg, Germany). Peripheral venous blood sample values including neutrophil, lymphocyte and platelet levels were recorded from the hospital database. The NLR, PLR, and SII were calculated as the proportion of the neutrophils to lymphocytes, platelets to lymphocytes, which of platelet $\times$ (neutrophil/lymphocyte). Reference values for neutrophil, lymphocyte, and platelet were 2.0$7.0 \times 10^{9} / \mathrm{L}, 0.8-4.0 \times 10^{9} / \mathrm{L}$, and $100-400 \times$ $10^{9} / \mathrm{L}$, respectively.

\section{Statistical Analysis}

Statistical Package for the Social Sciences 21.0 package program was used for statistical analysis (SPSS Inc., Chicago, IL USA). The compatibility of numerical data to normal distribution was tested with Shapiro-Wilks test. Relationships between categorical variables were tested with Chi-square test. To test for the presence of inter-group differences in continuous variables, parametric methods such as Anova-T test and Paired Sample-T test were used in cases when data were normally distributed, and nonparametric methods such as Kruskal-Wallis test and Mann-Whitney U test were used when data were not normally distributed. Tukey's Honest Significant Difference test was used for Anova-T test, and Dunn-Bonferroni test was used for KruskalWallis test as post-hoc analysis in paired comparisons. Multivariate logistic regression analysis was also performed after adjusting for age and gender to evaluate for biomarkers associated with XFG and XFS. Relationships between hematological indices and ocular parameters in XFG and XFS were analyzed by Spearman correlation. After Spearman correlation, a multivariate linear regression analysis adjusted for age and gender was performed to investigate the relationship between biomarkers and ocular parameters. Receiver operating character (ROC) curve analysis was performed to determine the sensitivity of the NLR, PLR and SII parameters of the cases. The area under the ROC curve (AUC) of each parameter was compared between the pairs. All reported P values were two tailed, and $\mathrm{P}<0.05$ was considered statistically significant.

\section{RESULTS}

The mean patient age was $76.91 \pm 11.5$ (45-92) years in the XFG group $(n=22), 73.00 \pm 9.52$ (54-95) years in the XFS group $(\mathrm{n}=41)$, and $74.17 \pm 11.43$ (35-96) in the control group $(\mathrm{n}=$ 71) $(P=0.398)$. Of the 22 cases with $X F G$ included in the study, 10 were female (45\%) and 12 were male (55\%). Of the 41 cases with XFS included in the study, 17 were female (41\%) and 24 were male (59\%). Of the 71 patients in the control group, 36 were female (51\%) and 35 were male $(49 \%)(\mathrm{P}=0.632)$. There was no inter-group difference in terms of platelet count, lymphocyte count, PLR, and SII parameters $(\mathrm{P}>0.05)$; however, there was a statistically significant difference between 
neutrophil count and NLR parameters $(\mathrm{P}=$ XFG group than in the XFS group $(\mathrm{P}=0.016$ and 0.019 and $\mathrm{P}=0.038$, respectively). $\mathrm{P}=0.040$, respectively) (Figure 1). However, Demographic characteristics of the cases, when the age- and gender-adjusted neutrophil, platelet, lymphocyte counts, and relationships of NLR, PLR and SII parameters of NLR, PLR and SII parameters are presented in table I. Neutrophil count was significantly higher in the XFG group than in the control group, and NLR was significantly higher in the the XFG and XFS groups were examined by logistic regression analysis, no significant intergroup differences were noted (Table II, $\mathrm{P}>$ $0.05)$.

Table I: Comparison of demographics and laboratory parameters between XFG, XFS and control groups.

\begin{tabular}{|c|c|c|c|c|c|c|c|}
\hline & $\begin{array}{l}\text { XFG group } \\
(n=22)\end{array}$ & $\begin{array}{l}\text { XFS group } \\
(\mathrm{n}=41)\end{array}$ & $\begin{array}{l}\text { Control } \\
(\mathrm{n}=71)\end{array}$ & $\mathrm{P}$ & $\begin{array}{c}\text { P } \\
\text { XFG } \\
\text { VS. } \\
\text { XFS }\end{array}$ & $\begin{array}{c}\mathrm{P} \\
\mathrm{XFG} \\
\text { vs. Control }\end{array}$ & $\begin{array}{c}\text { P } \\
\text { XFS } \\
\text { vs. Control }\end{array}$ \\
\hline Age, years & $76.91 \pm 11.5$ & $73.00 \pm 9.52$ & $74.17 \pm 11.43$ & 0.398* & 0.366 & 0.559 & 0.848 \\
\hline $\begin{array}{l}\text { Gender } \\
(\text { Female/Male) }\end{array}$ & $\begin{array}{l}10(45 \%) \\
12(55 \%)\end{array}$ & $\begin{array}{l}17(41 \%) \\
24(59 \%)\end{array}$ & $\begin{array}{l}36(51 \%) \\
35(49 \%)\end{array}$ & $0.632 \ddagger$ & 0.970 & 0.852 & 0.455 \\
\hline Neutrophil, $10^{9} / \mathrm{L}$ & $5.99(2.08-10.61)$ & $5.08(1.77-11.95)$ & $4.62(2.08-11.85)$ & $0.019 \dagger$ & 0.284 & 0.016 & 0.670 \\
\hline $\begin{array}{l}\text { Platelet, } \\
10^{9} / \mathrm{L}\end{array}$ & $252.91 \pm 63.42$ & $244.33 \pm 88.09$ & $260.32 \pm 71.11$ & $0.558^{*}$ & 0.903 & 0.915 & 0.529 \\
\hline Lymphocyte, $10^{9} / \mathrm{L}$ & $1.99 \pm 0.61$ & $2.37 \pm 1.01$ & $2.12 \pm 0.80$ & $0.199 *$ & 0.220 & 0.805 & 0.308 \\
\hline NLR & $2.97(1.20-7.29)$ & $1.91(0.83-9.26)$ & 2.17 (0.7- 9.26) & $0.038 \dagger$ & 0.040 & 0.082 & 0.990 \\
\hline PLR & $\begin{array}{c}116.36 \\
(81.87-224.84)\end{array}$ & $\begin{array}{c}101.5 \\
(4.77-388.14)\end{array}$ & $\begin{array}{c}122.73 \\
(58.21-388.14)\end{array}$ & $0.115 \dagger$ & 0.267 & 0.990 & 0.189 \\
\hline SII & $\begin{array}{c}781.36 \\
(242.87-1975.68)\end{array}$ & $\begin{array}{c}532.49 \\
(23.37-2334.50)\end{array}$ & $\begin{array}{c}564.89 \\
(195.2-2334.50)\end{array}$ & $0.091 \dagger$ & 0.090 & 0.246 & 0.990 \\
\hline
\end{tabular}

Data are expressed as mean \pm standard deviation, median (min-max) or number of cases (\%) as appropriate. ${ }^{*}$ Anova-T test. $\neq$ Chi-Squared Test. †Kruskal-Wallis test. Bolded values represent significant, $P<0.05$.

Tukey's Honest Significant Difference test was used for Anova-T test, and Dunn-Bonferroni test was used for Kruskal-Wallis test as post-hoc analysis in paired comparisons.

XFG, exfoliative glaucoma; XFS, exfoliative syndrome; NLR, neutrophil / lymphocyte ratio; PLR, platelet / lymphocyte ratio; SII, systemic immune inflammation index.

Clinical findings of the eyes of patients with XFG and XFS are summarized in table III. In both groups, there was no significant difference between the right and left eyes of the patients in terms of intraocular pressure (IOP), cup to disc ratio (C/D) and global RNFLT measurements (P $>0.05$ ). 

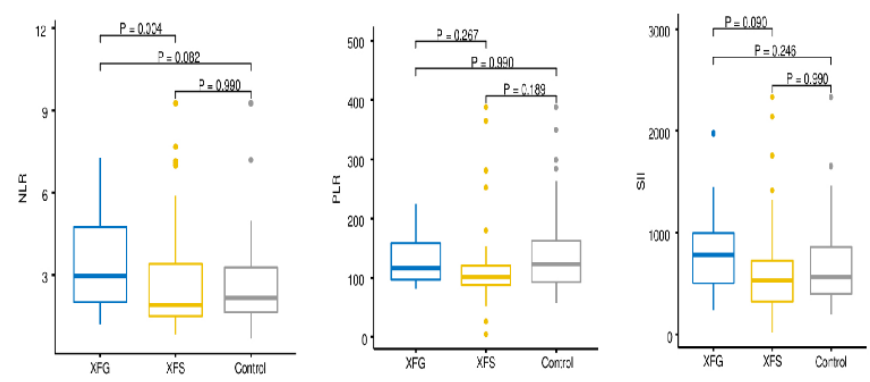

Figure 1: Paired group comparisons for NLR, PLR, and SII.

Paired group comparisons of neutrophil / lymphocyte ratio (NLR), platelet $/$ lymphocyte ratio (PLR), and systemic immune inflammation index (SII). $X F G$, exfoliative glaucoma; XFS, exfoliative syndrome.

Table II: The logistic regression analysis of NLR, PLR, and SII parameters between XFG and XFS groups.

\begin{tabular}{|l|c|c|c|c|}
\hline \multirow{2}{*}{} & \multirow{2}{*}{ OR } & \multirow{2}{*}{$\mathrm{P}$} & \multicolumn{2}{|c|}{$95 \%$ CI } \\
\cline { 3 - 5 } & & & Upper limit & Lower limit \\
\hline NLR & 0.883 & 0.420 & 0.647 & 1.198 \\
\hline PLR & 0.999 & 0.878 & 0.991 & 1.008 \\
\hline SII & 0.999 & 0.256 & 0.998 & 1.000 \\
\hline
\end{tabular}

$P$ values were calculated using logistic regression analysis (after adjusted for age and gender). NLR, neutrophil / lymphocyte ratio; PLR, platelet / lymphocyte ratio; SII, systemic immune inflammation index; $X F G$, exfoliative glaucoma; XFS, exfoliative syndrome; OR, odds ratio; CI, confidence interval.

Multiple linear regression analysis of the relationship between the NLR, PLR and SII parameters of the XFG and XFS groups and the IOP, C/D and global RNFLT values of their right eyes revealed no significant relationship between the blood parameters and eye measurements in both groups (Table IV, $\mathrm{P}>0.05$ ).
Table III: Comparison of ocular parameters between XFG and XFS groups.

\begin{tabular}{|c|c|c|c|}
\hline & $\begin{array}{c}\text { XFG group } \\
(\mathrm{n}=22) \\
\text { Mean } \pm \text { SD } \\
\text { Median (Min- } \\
\text { Max) }\end{array}$ & $\begin{array}{c}\text { XFS group } \\
(\mathrm{n}=41) \\
\text { Mean } \pm \text { SD } \\
\text { Median (Min- } \\
\text { Max) }\end{array}$ & $\mathrm{P}^{1}$ \\
\hline $\begin{array}{l}\text { Right IOP } \\
\text { (mmHg) }\end{array}$ & $\begin{array}{c}14.90 \pm 4.47 \\
14(9-24)\end{array}$ & $\begin{array}{c}11.61 \pm 2.30 \\
11(6-18)\end{array}$ & 0.004* \\
\hline Left IOP (mmHg) & $\begin{array}{c}14.95 \pm 4.18 \\
14(8-24)\end{array}$ & $\begin{array}{c}12.59 \pm 2.78 \\
12(8-20)\end{array}$ & 0.018* \\
\hline $\mathrm{P}^{2}$ & 0.431 & 0.051 & \\
\hline Right C/D & $\begin{array}{c}0.71 \pm 0.15 \\
0.75(0.4-0.9)\end{array}$ & $\begin{array}{c}0.32 \pm 0.06 \\
0.3(0.2-0.5)\end{array}$ & $<0.001^{*}$ \\
\hline Left C/D & $\begin{array}{c}0.67 \pm 0.18 \\
0.7(0.4-0.9)\end{array}$ & $\begin{array}{c}0.33 \pm 0.06 \\
0.3(0.2-0.5)\end{array}$ & $<0.001^{*}$ \\
\hline $\mathrm{P}^{2}$ & 0.260 & 0.323 & \\
\hline $\begin{array}{l}\text { Right global } \\
\text { RNFLT }(\mu \mathrm{m})\end{array}$ & $\begin{array}{l}76.27 \pm 20.98 \\
79.5(41-113)\end{array}$ & $\begin{array}{l}102.46 \pm 7.93 \\
101(90-119)\end{array}$ & $<0.001$ \\
\hline $\begin{array}{l}\text { Left global } \\
\text { RNFLT }(\mu \mathrm{m})\end{array}$ & $\begin{array}{c}73.64 \pm 21.83 \\
82(33-104)\end{array}$ & $\begin{array}{l}102.88 \pm 8.58 \\
100(86-121)\end{array}$ & $<0.001^{*}$ \\
\hline $\mathrm{P}^{2}$ & 0.668 & 0.754 & \\
\hline
\end{tabular}

P1: XFG vs. XFS groups, *Mann-Whitney U Test, $\square$ Welch T-test.

P2: Right vs. left eyes, Paired Sample-T test.

$X F G$, exfoliative glaucoma; XFS, exfoliative syndrome; $S D$, standard deviation; IOP, intraocular pressure; C/D; cup to disc ratio; RNFLT, retinal nerve fiber layer thickness.

Table IV: Multiple linear regression analysis for associations between NLR, PLR, SII and ocular parameters in XFG and XFS groups.

\begin{tabular}{|c|c|c|c|c|c|c|c|c|c|c|c|c|}
\hline & \multicolumn{6}{|c|}{ XFG group } & \multicolumn{6}{|c|}{ XFS group } \\
\hline & \multicolumn{2}{|c|}{ IOP } & \multicolumn{2}{|c|}{ C/D } & \multicolumn{2}{|c|}{ gRNFLT } & \multicolumn{2}{|c|}{ IOP } & \multicolumn{2}{|c|}{ C/D } & \multicolumn{2}{|c|}{ gRNFLT } \\
\hline & $\beta$ & $\mathrm{P}$ & $\beta$ & $\mathrm{P}$ & $\beta$ & $\mathrm{P}$ & $\beta$ & $\mathrm{P}$ & $\beta$ & $\mathrm{P}$ & $\beta$ & $\mathrm{P}$ \\
\hline NLR & -0.001 & 0.995 & 0.002 & 0.720 & 0.376 & 0.610 & 0.081 & 0.899 & 0.022 & 0.274 & -1.515 & 0.595 \\
\hline PLR & 0.001 & 0.828 & $<0.001$ & 0.885 & 0.022 & 0.227 & 0.021 & 0.408 & 0.001 & 0.237 & 0.054 & 0.615 \\
\hline SII & $<0.001$ & 0.884 & $<0.001$ & 0.817 & 0.003 & 0.288 & $<0.001$ & 0.856 & $<0.001$ & 0.491 & -0.003 & 0.766 \\
\hline
\end{tabular}

$P$ values were calculated using multiple linear regression analysis (after adjusted for age and gender). NLR, neutrophil / lymphocyte ratio; PLR, platelet / lymphocyte ratio; SII, systemic immune inflammation index; XFG, exfoliative glaucoma; XFS, exfoliative syndrome; IOP, intraocular pressure; C/D; cup to disc ratio; gRNFLT, global retinal nerve fiber layer thickness. 
To distinguish between cases with XFG, cases with XFS and control cases, the areas under the curve of the NLR, PLR and SII parameters were analyzed by ROC curve analysis (Figure 2, 3 and 4). Neutrophil / lymphocyte ratio was found to be the most acceptable discriminant parameter when comparing XFG group with the XFS and control groups (AUC $=0.678$, AUC $=0.663$, respectively) . Platelet / lymphocyte ratio was found to be the best discriminant parameter between the XFS and control groups $(\mathrm{AUC}=0.605)$.

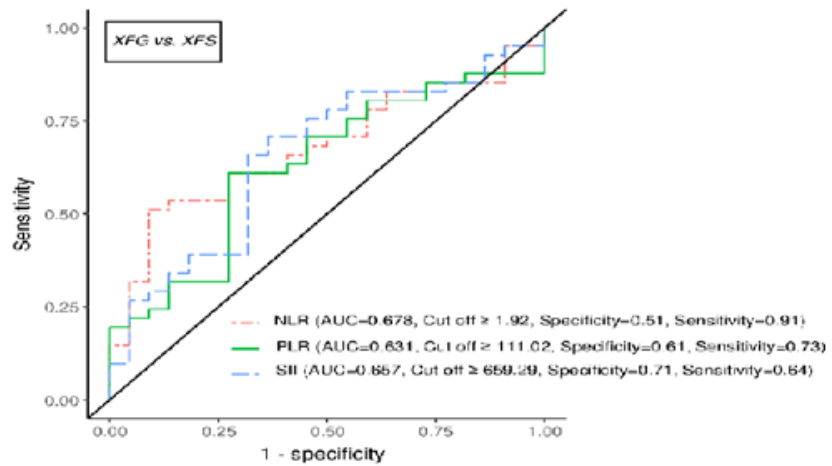

Figure 2: ROC analysis for discrimination between XFG and XFS groups.

Receiver operating characteristics curve (ROC) analysis for discrimination between exfoliative glaucoma $(X F G)$ patients $(n=22)$ and exfoliative syndrome (XFS) patients $(n=41)$. NLR, neutrophil / lymphocyte ratio; $P L R$, platelet / lymphocyte ratio; SII, systemic immune inflammation index.

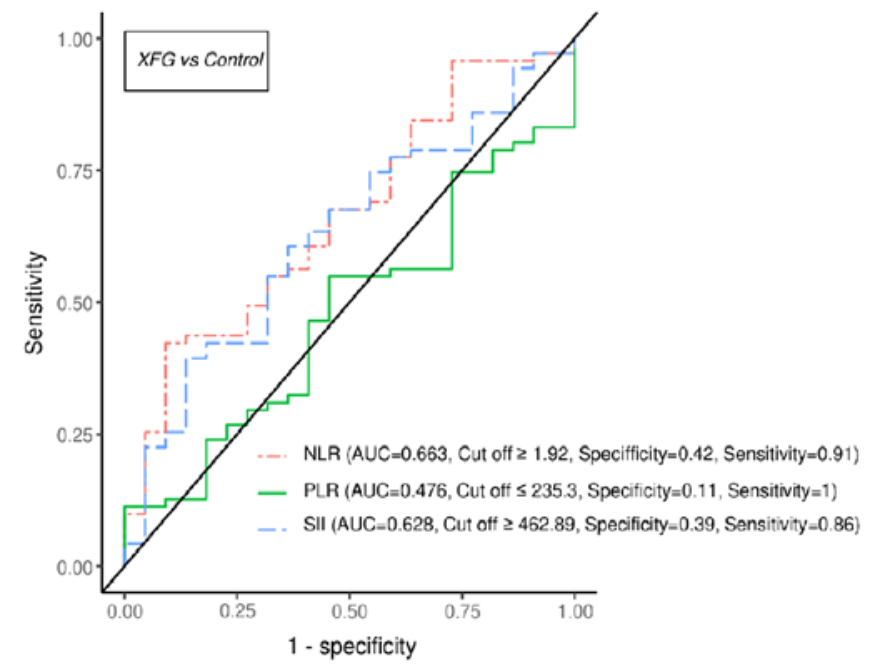

Figure 3: ROC analysis for discrimination between XFG and control groups.

Receiver operating characteristics curve (ROC) analysis for discrimination between exfoliative glaucoma $(X F G)$ patients $(n=22)$ and controls $(n=$ 71). NLR, neutrophil / lymphocyte ratio; PLR, platelet / lymphocyte ratio; SII, systemic immune inflammation index.

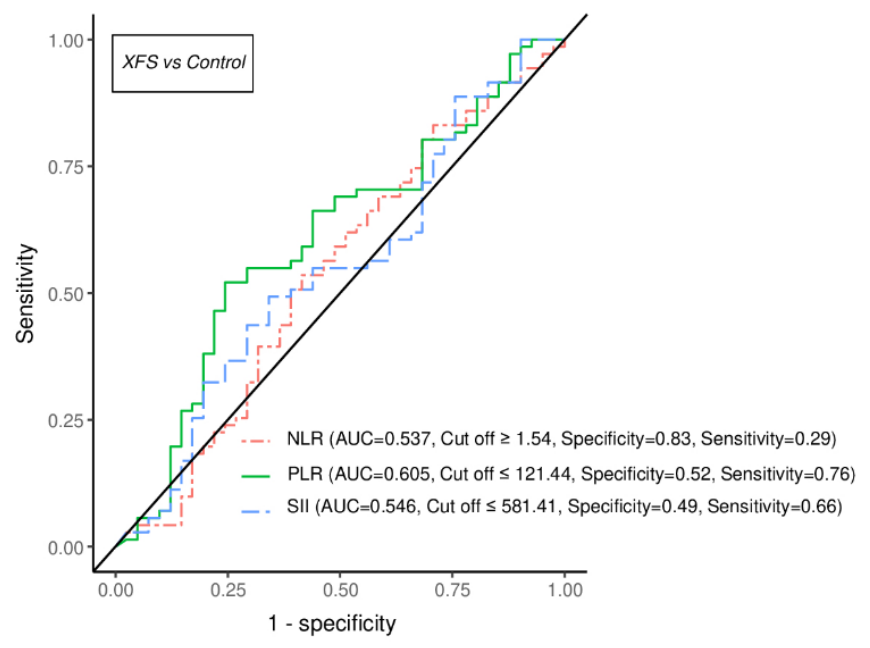

Figure 4: ROC analysis for discrimination between XFS and control groups.

Receiver operating characteristics curve (ROC) analysis for discrimination between exfoliative syndrome (XFS) patients $(n=41)$ and controls $(n=$ 71). NLR, neutrophil / lymphocyte ratio; PLR, platelet / lymphocyte ratio; SII, systemic immune inflammation index.

\section{DISCUSSION}

Among evaluated hematological parameters, although the NLR values of the subjects with XFG were greater than those of the subjects with XFS, after correcting for confounding factors including age and gender, these differences did not persist. Furthermore, as per the age- and gender-adjusted outcomes of the study, multiple linear regressions of the association between the NLR, PLR and SII parameters and the ocular parameters of the XFG and XFS groups revealed no significant relationship between the blood parameters and ocular measurements. Considering the fact that NLR had the best AUC when comparing XFG and XFS groups, it may be the most acceptable discriminant parameter between XFG and XFS patients. Additionally, PLR may be the most reliable discriminant parameter between XFS and healthy individuals.

Several studies have already revealed that various types of glaucoma such as primary open angle, secondary open angle, primary angle closure, normal tension, and neovascular glaucoma may be associated with inflammatory processes ${ }^{10-14,16,17,19-22}$. The pathogenesis of 
exfoliation is multifactorial and remains unclear but increased oxidative stress, endothelial dysfunction, and ocular inflammation are the likely leading cause. Hence, increased inflammatory biomarkers have been a investigate subject in exfoliation ${ }^{10,11,13}$. Comparable retrospective studies have been conducted by researchers who analyzed the NLR and PLR levels in XFS, XFG and healthy individuals. Ozgonul et al. ${ }^{11}$ performed a study whereby they considered, 29 patients with XFG, 34 patients with XFS, and 42 healthy subjects. They reported that NLR and PLR may be useful for predicting the prognosis of XFS patients and progression to $\mathrm{XFG}^{11}$. In another study including 55 patients with XFS, ${ }^{19}$ patients with XFG, and 48 healthy control subjects, Kurtul et al. ${ }^{13}$ found an association of elevated NLR with XFS and XFG. On the contrary to above mentioned study, our findings did not ensure evidence for the association between hematological parameters and exfoliation status even with or without glaucoma, after the outcomes were adjusted for age and gender.

In the present study, NLR value was significantly predictive to discriminate XFG subjects than XFS subjects. Besides, we found PLR level significant to discriminate the XFS subjects and the controls. On the contrary to the findings of Ozgonul et al. ${ }^{11}$, NLR was thought more important in anticipating XFG due to it being critical within the exfoliative spectrum with glaucomatous damage (XFG phase). On the other hand, deciding PLR as critical marker within the XFS proposes that PLR can be utilized as a discriminant marker in exfoliative spectrum without glaucomatous damage (XFS phase).

Currently, SII is recommended for predicting the prognosis of systemic inflammatory diseases and malignancies ${ }^{6-8}$. There is a limited number of studies investigating the association between SII and ocular diseases such as glaucoma in the literature. In the retrospective case-control study included 240 subjects with primary open angle glaucoma and 300 healthy individuals, Tang et al. ${ }^{22}$ reported that higher SII and NLR values might serve as readily available inflammatory biomarkers in primary open angle glaucoma subjects. In our study, we aimed to evaluate whether SII can be a differential parameter in XFG, the most common type of open angle glaucoma, and XFS, its precursor form. In similar way to the abovementioned study, determining SII (AUC $=0.657$ ) as significant parameter after NLR (AUC $=0.678)$ when comparing XFG group with XFS group suggests that SII can be used as a supportive indicator in addition to NLR.

This research has some limitations. It was limited by its small sample size, retrospective and cross-sectional design. Patients with exfoliation experience different challenges. Because not every subject with exfoliation has glaucoma, it is important to detect when glaucomatous changes start. The XFG patients involved in the study were administered different medications for different durations; hence, the study outcomes could not be generalized.

In conclusion, the main strength of this research is that although we did not find any difference between groups, our research is the one that to compare the age- and gender-adjusted laboratory indicators including NLR, PLR, and SII, and ocular parameters between in the patients with XFG and XFS. On the other hand, the higher diagnostic discrimination ability of NLR level between XFG and XFS groups according to the results of our study supports other studies in the literature. It is still recommended that a longitudinal study be conducted in the future to determine any possible link between hematological inflammatory indicators and various types of glaucoma.

Author Contributions: Both authors contributed to the study conception and design. 
Material preparation, data collection and analysis were performed by both of the authors. The first draft of the manuscript was written by Atılım Armağan Demirtaş and both authors commented on previous versions of the manuscript. Both authors read and approved the final manuscript.

Ethics Approval: All procedures performed in studies involving human participants were in accordance with the ethical standards of the institutional and/or national research committee and with the 1964 Helsinki Declaration and its later amendments or comparable ethical standards. The study was approved by the Ethics Committee of Diyarbakır Gazi Yaşargil Training and Research Hospital, Diyarbakır, Turkey (decision date: 14 June 2019, No. 292).

Conflicts of Interest: The authors declare that they have no competing interest.

Financial Dislosure: There are no financial supports.

\section{REFERENCES}

1. Serfőző G, Horváth T, Földesi I, Rafael B, von Känel $\mathrm{R}$, Keresztes M. The Monocyte-to-Lymphocyte Ratio Correlates with Psycho-Neuro-Inflammatory Factors in Patients with Stable Coronary Artery Disease. Neuroimmunomodulation. 2016; 23: 6774.

2. Mertoglu C, Gunay M. Neutrophil-Lymphocyte ratio and Platelet-Lymphocyte ratio as useful predictive markers of prediabetes and diabetes mellitus. Diabetes Metab Syndr. 2017; 11: S127S131.

3. Kurtul BE, Kurtul A, Altiaylik Ozer P, Kabatas EU, Ertugrul GT. Serum lipid levels in pseudoexfoliation syndrome. Semin Ophthalmol. 2017; 32: 281-4.

4. Wang Q Ma J, Jiang Z, Ming L. Prognostic value of neutrophil-to-lymphocyte ratio and platelet-tolymphocyte ratio in acute pulmonary embolism: a systematic review and meta-analysis. Int Angiol. 2018; 37: 4-11.
5. Kurtul BE, Ozer PA. Neutrophil-to-lymphocyte ratio in ocular diseases: a systematic review. Int J Ophthalmol. 2019; 12: 1951-8.

6. Lv Y, Zhang S, Liu Z, Tian Y, Liang N, Zhang J. Prognostic value of preoperative neutrophil to lymphocyte ratio is superior to systemic immune inflammation index for survival in patients with Glioblastoma. Clin Neurol Neurosurg. 2019; 181: 247.

7. Mirili C, Paydaș S, Yılmaz A, et al. Prognostic Significance of Dynammic Inflammatory Indexes in Cases Renal Cell Canser Treated by Tyrosine Kinase Inhibitor (TKI). Acta Oncologica Turcica. 2019; 52: 372-8.

8. Fest J, Ruiter R, Mulder M, et al. The systemic immune-inflammation index is associated with an increased risk of incident cancer-A populationbased cohort study. Int J Cancer. 2020; 146: 692-8.

9. Yelgeç NS, Karataş MB, Karabay YC, et al. The Relationship Between Acute Renal Failure After Transcatheter Aortic Valve Replacement and Preprocedural Neutrophil To Lymphocyte Ratio. Dicle Med J. 2020; 7: 1-9.

10. Türkyılmaz K, Öner V, Kırbas A, et al. Serum YKL40 levels as a novel marker of inflammation and endothelial dysfunction in patients with pseudoexfoliation syndrome. Eye. 2013; 27: 854-9.

11. Ozgonul C, Sertoglu E, Mumcuoglu T, Ozge G, Gokce G. Prediction of Pseudoexfoliation Syndrome and Pseudoexfoliation Glaucoma by Using Neutrophil to Lymphocyte Ratio and Platelet to Lymphocyte Ratio. Ocul Immunol Inflamm. 2016; 24: 665-70.

12. Ozgonul C, Sertoglu E, Mumcuoglu T, Kucukevcilioglu M. Neutrophil-to-Lymphocyte Ratio and Platelet-to-Lymphocyte Ratio as Novel Biomarkers of Primary Open-Angle Glaucoma. J Glaucoma. 2016; 25: e815-e820.

13. Kurtul BE, Ozer PA, Kabatas EU. Elevated neutrophil-to-lymphocyte ratio in pseudoexfoliation syndrome. Eye (Lond). 2016; 30: 1045-8.

14. Arıkan S, Erşan İ, Kara S, et al. Neutrophil Lymphocyte Ratio in Different Types of Glaucoma. Glokom Katarakt. 2016; 11: 221-4. 
15. Yüksel N, Mutlu M. Kuru Göz Hastalarında Nötrofil Lenfosit Oranının Oküler Yüzey Bulguları ile İlişkisi. MN Oftalmololoji. 2016; 23: 196-9.

16. Li S, Cao W, Han J, Tang B, Sun X. The diagnostic value of white blood cell, neutrophil, neutrophil-to-lymphocyte ratio, and lymphocyte-tomonocyte ratio in patients with primary angle closure glaucoma. Oncotarget. 2017; 8: 68984-95.

17. Atalay K, Kaldirim Erdogan H, Kirgiz A, Asik Nacaroglu S. Predictive role of neutrophil-tolymphocyte ratio and platelet-to-lymphocyte ratio in normal-tension glaucoma. Med Hypotheses. 2017; 103: 54-6.

18. Dikkaya F, Karaman Erdur S, Ozsutcu M, Aydin R, Kocabora MS, Aras $\mathrm{Cl}$. The significance of neutrophil-to-lymphocyte ratio in idiopathic epiretinal membrane. Int Ophthalmol. 2018; 38: 1393-7.

19. Zhang A, Ning L, Han J, et al. Neutrophil-ToLymphocyte Ratio as a Potential Biomarker of Neovascular Glaucoma. Ocul Immunol Inflamm. 2019: 1-8.
20. Atalay K, Erdogan Kaldirim H, Kirgiz A, Asik Nacaroglu S. Neutrophil to Lymphocyte and Platelet to Lymphocyte Ratios in Normal Tension Glaucoma. Med Hypothesis Discov Innov Ophthalmol. 2019; 8: 278-82.

21. Mirza E, Oltulu R, Katipoğlu Z, Mirza GD, Özkağnıcl A. Monocyte/HDL Ratio and Lymphocyte/Monocyte Ratio in Patients with Pseudoexfoliation Syndrome. Ocul Immunol Inflamm. 2020; 28: 142-6.

22. Tang B, Li S, Han J, Cao W, Sun X. Associations between Blood Cell Profiles and Primary OpenAngle Glaucoma: A Retrospective Case-Control Study. Ophthalmic Res. 2020; 63: 413-22.

23. Yildiz Balci S, Turan-Vural E, Turkyilmaz O, Esen F, Aksaray S. Complete blood count parameters and neutrophil-to-lymphocyte ratio values as markers for differentiation between systemic infectious and non-infectious uveitis. Int Ophthalmol. 2020; 40: 3033-41. 